\title{
Hope, Politics and Risk: The Case of Chinese Dam in Nigeria
}

\author{
Olorunfemi Felix ${ }^{1}$, Tan-Mullins May ${ }^{2}$, Mohan Giles ${ }^{3}$, Siciliano Giuseppina ${ }^{4} \&$ Urban Frauke $^{4}$ \\ ${ }^{1}$ Nigerian Institute of Social and Economic Research, Ojoo, Ibadan, Nigeria \\ ${ }^{2}$ School of International Studies, The University of Nottingham Ningbo, China \\ ${ }^{3}$ The Open University London, UK \\ ${ }^{4}$ School of Oriental and African Studies, University of London, UK \\ Correspondence: Olorunfemi Felix, Nigerian Institute of Social and Economic Research, Ibadan, Nigeria. Tel: \\ 234-8033-950-837.E-mail: felixba2000@yahoo.com
}

Received: June 27, 2016

Accepted: July 26, 2016

Online Published: June 24, 2017

doi:10.5539/eer.v7n2p1

URL: https://doi.org/10.5539/eer.v7n2p1

\begin{abstract}
The rise of Chinese infrastructure investment in Africa has raised a set of questions about whose development agendas are being fulfilled by such projects, where the power lies in these negotiations, and how local communities are impacted by the projects. Current assumptions see China as holding the power in these relations and that its state-backed transnational corporations unilaterally get their way. This paper challenges these simplistic assumptions by examining the case of a 'failed' Chinese project - the Zamfara Dam in Northern Nigeria - and in doing so makes a case for the role of African political agency in brokering Chinese engagement. The dam project was initiated in 2008 between the Zamfara State government and the China Geo-Engineering Corporation; funding was supposed to come from the Chinese ExIm Bank. After the initial assessment and community consultations that spanned three years, the project failed to take off. Primary data is used to understand the process of failure and shows that the dam was initiated based on political expediency rather than the actual drive for development. It was brokered between the elites of China, Nigeria and Zamfara state and so failed to gain wider legitimacy and accountability. Also, in the drive to see the project initiated statutory shortcuts were taken. Critically, consultation was not broad based even among the state government officials and the communities. The initiation of the project did not follow the laid down procedure of the Federal Ministry of Water Resources. Given that largely political factors played a significant role in the failure of the project, it is suggested that motivation for and implementation of development projects of this nature should transcend political whims and caprices of politicians and ensuring more transparency and broad consultation.
\end{abstract}

Keywords: China; Hydrodams, Nigeria, Government, Corporations, Consultation

\section{Introduction}

The acute needs for improved water resources and energy management in Africa have renewed the interest in large dams. The energy agenda is particularly pressing, because of concerns about climate change, the Sustainable Development Goals (SDGs), variable crude oil prices, prevailing energy poverty in many poorer countries and alternative sources of funding for large dams (IRN 2007, Alhassan, 2009). Infrastructure investments in Africa have not kept pace with growth in demand, creating a huge deficit. Less than $40 \%$ of the continent's population has access to electricity, about a third of the rural population has access to roads and only $5 \%$ of agriculture is under irrigation. The situation is no better for social infrastructure, with only $34 \%$ of the population having access to improved sanitation and a slightly better situation for clean water at about $65 \%$ (World Bank, 2015; African Development Bank, 2010). Furthermore, Africa faces higher access costs compared to other developing countries.

According to Castellano et al. (2015), sub-Saharan Africa is woefully short of electricity. Whether considering energy access, installed capacity, or overall consumption, there is significant underdevelopment in the power sector. From an electricity-access point of view, sub-Saharan Africa's situation is the world's worst (besides India). It has 13 percent of the world's population, but 48 percent of the share of the global population without access to electricity. This means that almost 600 million people in sub-Saharan Africa lack access to electricity (IEA, 2015). It is projected (Castellano et al, 2015) that sub-Saharan Africa will consume nearly 1,600 terawatt hours by 2040, four times what was used in 2010 . 
The recent attention on large dams reawakens longer standing interests from the early post-independence period when dams were seen as essential for modernisation and industrialisation. However, from the early 1980s structural adjustment programmes and the World Commission on Dams (WCD) combined to curtail large dam projects. Set against this growing demand are new sources of finance and construction expertise for large dam projects, particularly from China (Bosshard 2009, IRN, 2007). The Chinese have emerged as major infrastructure providers in Africa through various forms of financing deals, tied to the use of Chinese state-owned dam building firms for construction and procurement (IRN, 2007). As a result China's foreign direct investment (FDI) stock in Africa has drastically increased over the past years: from US\$ 56 million in 1996 to US\$ 15 billion in 2012 (Grimm et al, 2014).

Besides the vast opportunities for Africa, and much like any other outside assistance and co-operation, this Chinese investment comes with challenges that need to be managed and mitigated. Much discussed are the governance challenges that China might or might not present to African states and societies (Cisse et al, 2014). Some critics argue that China 'exports' its weak regulatory standards to Africa, especially around environmental impacts, which plays into an already poor governance environment thereby creating a toxic mix of malfeasance (Haglund 2009). Labour costs and standards are another area where the Chinese are accused of undercutting local standards and contributing to a wider preacrity of formal labour markets (Corkin et al, 2008). Geopolitically, many assume that an all-powerful China pushes through its projects and so compromises the sovereignty of African states, in a new version of imperialism (Naidu, 2007). In this paper we focus on the Zamfara Dam in Northern Nigeria which was first mooted in 2008 but failed to get beyond the consultation phase.

In order to learn from failure, this paper addresses the Chinese drivers of hydropower investment in Africa as well as the political dynamics of the recipient country, in this case Nigeria. In doing so we focus on the capacities of the Nigerian state, understood in complex terms as federalised and multi-scalar. The case study reveals a process of elite brokerage which bypassed channels of accountability which resulted in very weak consultation with dam-affected communities. The paper is divided into five sections. Following this introductory section, an actor-oriented 'Political ecology of the Asian Drivers' framework is set out which provides the conceptual basis for the paper and the methodology used for the study. The third section looks at the range of Chinese actors engaging in Nigeria's development. Next we analysed the reasons for failure and the last section provides a conclusion of the paper.

\section{Actor-Oriented 'Political Ecology of the Asian Drivers' Framework and Methodology Conceptual Framework}

This research uses the conceptual framework of the 'Political Ecology of the Asian Drivers'. This framework is a hybrid approach that draws on the political ecology of China's engagement in overseas hydropower projects and the Asian Drivers for explaining the rise of China and its global, national and local impacts. This is outlined below:

The majority of earlier work on China's engagement with low and middle income countries (LMICs) has been speculative (Mohan 2008), and Africa focused (Alden et al 2008). Crucially these studies have largely ignored the environmental consequences of China's internationalisation, particularly in Asia and Africa. Understanding a complex set of international actors, interdependencies and ecological impacts necessitates a broad theoretical framework (Urban et al, 2013).

Concerning the political ecology, two key aspects are picked up in our framework: spatiality and power. First, political ecology integrates spatially heterogeneous processes and actors within a framework of ecological, social, economic, and political relations that links inquiry across scales of analysis (e.g. Bury 2008, Bryant and Bailey 1997; Peet and Watts 2004). Scholars have focused on the impacts of state policies on resource utilization (Paulson and Gezon 2003; Peluso 1996, Whitehead and Jones 2007), the importance of local agency in natural resource management, and social movements as responses to environmental degradation (Peet and Watts 2004). Second, power relations between different actors are at the heart of the political ecology framework (Tan-Mullins, 2007) such that it is typically "power-laden rather than politically inert" (Biersack 2006: 5). Assessing the unequal power relations between actors provides a way to explain the uneven distribution of access to environmental resources (Bryant, 1997) and the differential outcomes of these access and allocation.

One way to combine both spatiality and power is through an actor-oriented perspective (Long 1994). Actor-oriented approaches in political ecology emerged in realisation of the vital importance of actors' interests and how it determines the behaviour of actors operating at a variety of scales influencing local interaction with resources. A key advantage of this approach is that it allows for a more complex understanding of the 
interactions between these actors. One of the shortcomings of much political ecology research is its tendency to essentialize actors such as the state, NGOs, or local community organizations and treat them as monolithic entities (Bury, 2008).

Studies of corporate strategy have emphasized that corporations, even those faced with the same circumstances, make divergent decisions that have far-reaching consequences for both the workers and places affected by their activities (e.g. Sklair 2001). As the global system of natural resource extraction and industrial production has been unified under a system of neoliberal economic and social policies, free trade, and investment, transnational corporations have also initiated profound transformations of natural environments that affect not only global and regional ecological processes, but also the local populations that are dependent upon them for survival (Bury, 2008). In our study we further complicate this picture by focusing on TNCs from the 'emerging' economy of China. Importantly Chinese TNCs are state-backed which blurs the line between the corporate and the state realms (Tiffen, 2014, Jiang and Mirza, 2010). Power from TNCs are then manifested across spatiality and boundaries in host countries through the channels of interaction and influence mentioned above.

We combine this theoretical framework of political ecology with the distinctive approach of the 'Asian Drivers' and their impacts. This framework has already been used by the authors in an amended form to assess the motives and implications of Chinese investments in the hydropower sector in the Greater Mekong Sub-Region (Urban et al, 2013ab). The Asian Drivers framework developed by Humphrey and Messner (2005, 2006), Schmitz (2006), and Kaplinsky and Messner (2008) assesses China’s direct and indirect impacts as a Rising Power and its channels of interaction with LMICs. There is a mixture of complementary and competitive economic impacts and positive and negative impacts in relation to society and the environment (Kaplinsky \& Messner 2008). Urban et al (2013; 2011) advanced the Asian Drivers Framework further by addressing the motives, actors and beneficiaries in addition to impacts to analyse in more depth how, why and with which impacts Chinese actors engage in LMICs.

Taken together this framework of the 'Political Ecology of the Asian Drivers' enables us to address how Chinese investment strategies are coordinated vis-à-vis low and middle income countries (LMICs); their impacts on local social and environmental conditions in recipient countries; the effects on local and regional governance; and the implications for both UK hydropower firms and OECD aid programmes. This specific paper looks at a smaller part of these broader research questions and challenges the simplistic assumptions that China-Africa relationships for large infrastructure projects like dams are driven mainly by an all-powerful China by examining the case of a 'failed' Chinese project - the Zamfara Dam in Northern Nigeria - and in doing so makes a case for the role of African political agency in brokering Chinese engagement.

\section{Methodology}

To analyze the actors involved in the hydropower sector in Nigeria and the Zamfara project a stakeholder mapping approach was used. A stakeholder mapping is commonly used to analyze formal and informal interactions between different actors by focusing on the network of actors instead of their individual attributes or formal hierarchical structures (Schiffer and Hauk, 2010)(Note 1). We used the Net-Mapping Approach for the stakeholder analysis to determine key stakeholders, direct and indirect links to other stakeholders and power relations (Schiffer, 2007).

The methodology includes detailed fieldwork at the proposed dam site in Nigeria and in China. For the Zamfara dam, we conducted 149 surveys with local communities directly affected by the proposed dam through resettlements, 8 focus group discussion (FGDs) with the same affected communities (of which about $50 \%$ with women and 40\% with men, each FGD was composed of about 5-10 people). This involved people from in nine villages around the proposed dam site in August and September 2014. The communities in which the fieldwork was conducted are located in the Zamfara State (Figure 1) and included: Duhu, Gotawa, Kaface, Kuturu, Mokosa, Rimni, Tsakauna, Tungar Bazace, Tungar Labbo Buzu.

We also conducted 5 semi-structured interviews with institutional actors from hydropower firms, government authorities in Nigeria, as well as 23 semi-structured interviews with Chinese actors such as dam-builders most importantly China Geo-Engineering Corporation (CGC) in Gusau, Northern Nigeria, regulators and financiers. This makes a total of 36 interviews and 8 FGDs that we draw on for this paper, see Table 1. 


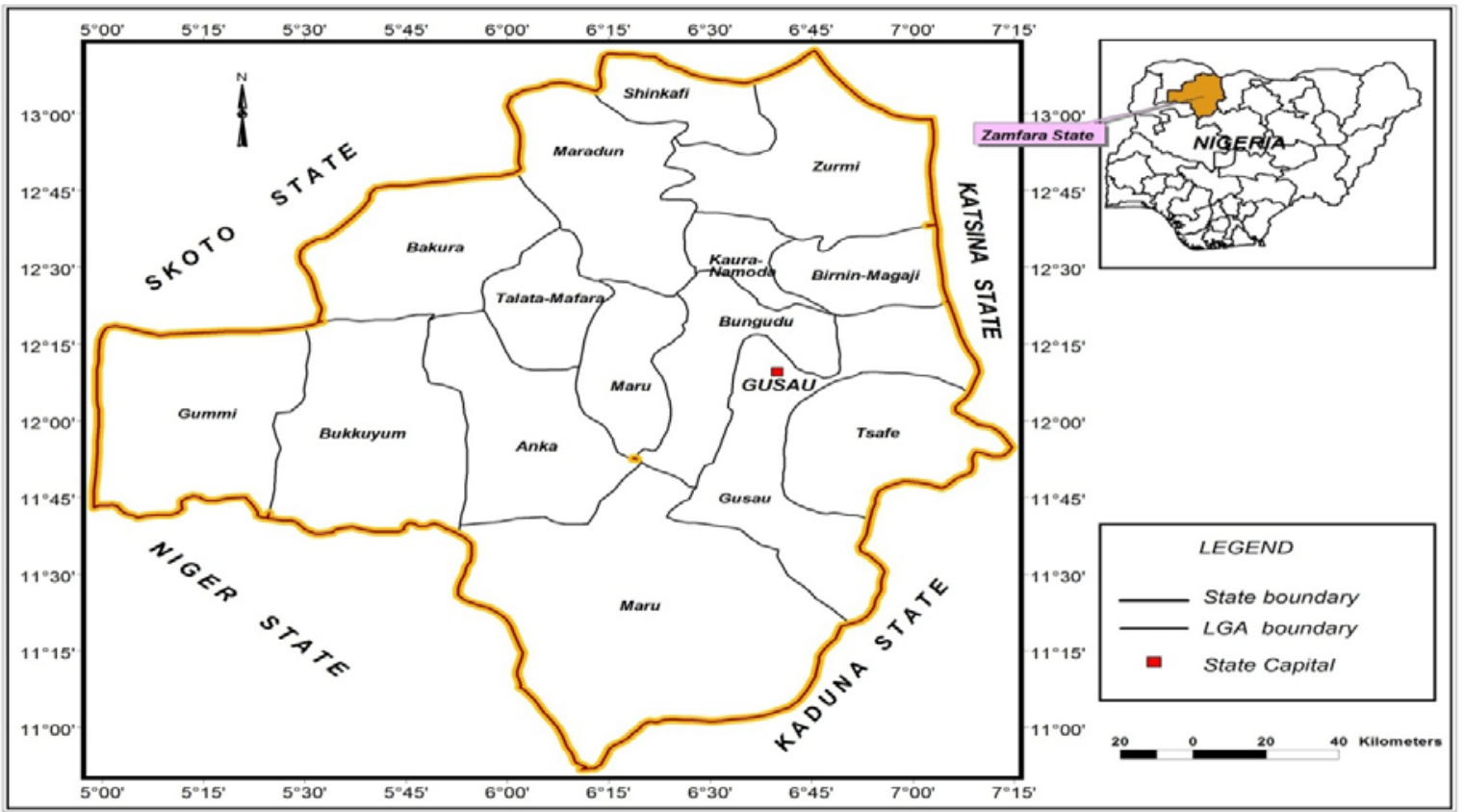

Figure 1. Map of Zamfara State

Table 1. Interviews and FGDs conducted in 2014 and 2015 for the Zamfara dam research.

\begin{tabular}{|c|c|c|c|}
\hline & Community members & $\begin{array}{l}\text { Nigerian } \\
\text { institutional actors }\end{array}$ & Chinese institutional actors \\
\hline $\begin{array}{l}\text { Number of } \\
\text { interviews / surveys }\end{array}$ & 149 surveys & 5 & 23 \\
\hline $\begin{array}{l}\text { Number of focus } \\
\text { group } \\
\text { discussions }\end{array}$ & 8 , totaling about 60 people & - & - \\
\hline Target group & $\begin{array}{l}\text { Members of local } \\
\text { communities from the } \\
\text { villages of Duhu, Gotawa, } \\
\text { Kaface, Kuturu, Mokosa, } \\
\text { Rimni, Tsakauna, Tungar } \\
\text { Bazace, Tungar Labbo } \\
\text { Buzu in Zamfara State, } \\
\text { Northern Nigeria }\end{array}$ & $\begin{array}{l}\text { National, state } \\
\text { and local } \\
\text { governmen } \\
\text { t } \\
\text { authorities, } \\
\text { hydropowe } \\
\text { r firms }\end{array}$ & $\begin{array}{l}\text { Dam-builders like China } \\
\text { Geo-Engineering } \\
\text { Corporation CGC, } \\
\text { financiers likeExIm } \\
\text { Bank, Chinese } \\
\text { ministries (MOFCOM, } \\
\text { MFA, MEP) and } \\
\text { regulators }\end{array}$ \\
\hline
\end{tabular}

The interviews had the purpose to identify the relevant actors in the hydropower sector in Nigeria, as well as to understand the consultation and contract negotiation process between the federal, state and local government authorities, local communities and potential impacts of the dam, in-depth interviews were conducted with government officials at the federal and state levels as well as traditional rulers in the communities.

In addition to this qualitative primary information, we used quantitative secondary data from International River's extensive database which includes comprehensive up-to-date data about each of China's hydropower projects worldwide (e.g. contractor, developer, financier, costs, size, location, environmental and social implications). We also compiled secondary data to assess the environmental impacts of dams and their governance implications by examining the EIA reports of the dams. We also analysed dam project documentation and firm strategies, such as Sinohydro's environmental and social strategies.

We analysed the qualitative data by categorising and coding the sources as a means of comparing and contrasting interpretations of events (Wolcott, 1994). We used the Nvivo 10 software to analyse the interview and focus group consultation data. These were analysed using narrative analysis (Wiles et al, 2005) rather than 
conventional 'code and retrieve' since the former allows for more layers of embodied meaning to be revealed by including narrative style. This allows us to compare several cases to be able to draw parallels from similar findings and flag up any differences (Yin, 2009).

\section{The Chinese as a Major Actor in Nigeria's Infrastructure Sector and the Zamfara Dam Project}

Our political ecology framework focuses on the channels of interaction between Chinese actors on the one hand and Nigerian actors on the other. Here we set out the broad relationships before focusing in on the particularities of the Zamfara Dam. China has become an important and influential player in the Nigerian economy (Obayuwana, 2013; Nigerian Compass, 2012; Alao, 2010; Babatunde and Low, 2008; Ukaoha, 2009). The extensive economic links between the two countries cover a broad range of sectors from construction and retailing to manufacturing and oil production. A number of incentives drive China's commercial engagement with Nigeria. Principal among these is China's increasing need for energy sources and raw materials to fuel its rapidly growing economy, as well as developing new markets for Chinese goods.

\section{China-Nigeria Relations}

By 2013, Nigeria had become China's second biggest African trading partner (Obayuwana, 2013), and the second largest Chinese export destination on the continent. Trade between the two countries accounted for nearly one third of the trade between China and the whole of West Africa, indicating the importance of Nigeria to China's entry into the regional market. Nigeria's investment incentives, along with its massive reserves of oil and gas, appear to have succeeded in attracting the attention of Chinese investors. Nigeria occupied the second position (after South Africa) among the ranks of African host countries for Chinese Foreign Direct Investment (FDI) between 2003 and 2009. Chinese investment in Nigeria rose from US\$6 billion in 2009 to US $\$ 8$ billion in 2010 (Center for Chinese Studies, 2011) and US\$ 8.92 billion in 2011 (Obayuwana, 2013).

China has developed one of the world's largest and most competitive construction industries, with particular expertise in the civil works critical for infrastructural development (Foster et al, 2008; Babatunde and Low, 2013). China's involvement in Africa's construction and infrastructure sectors has proved most effective in building relations with African governments - increasing influence and expanding access to natural resources on the continent through resource-backed infrastructure loans (Center for Chinese Studies, 2006). China has been involved in the construction of power plants, railways, roads, bridges and dams in different parts of Nigeria (Nigerian Compass, 2012; Babatunde \& Low, 2013). Chinese companies and Chinese banks are now the biggest builders and financiers of global dams (International River, 2013). In 2012, Chinese companies took part in construction of 308 dams and hydroelectric plants in 70 countries in the world, with 85 dams constructed in Africa (Kılıç 2013).

Although these broad China-Africa relationships have generally been mutually beneficial, with both sides looking for ways of strengthening it, there have also been some problems. To a large extent, the difficulties in the relationship have been due to the terms of the contracts drawn up between the two countries and the character of the business and political environment in Nigeria (Alao, 2010). According to Vines et al (2009), Chinese oil companies were less successful in Nigeria compared to Angola because they failed to understand the complex and dynamic nature of the Nigerian polity. Allegations about discriminatory/racist management styles (Deng, 2011), importation of Chinese labour, non-compliance with technology transfer agreements (Alike, 2011), and proliferation of shoddy consumer goods (Utomi, 2008) cast shadows over Chinese firms' operations in Nigeria (Babatunde \& Low, 2013). Whatever the efficacy of these claims about the Chinese firms, they have undoubtedly brought intense competition into the Nigerian construction industry.

\section{Nigeria's Hydropower Sector}

The potential for hydropower in Nigeria is significant. In terms of existing capacity Ofoezie (2002) reported that of the 323 dams in Nigeria, 106 were classed as 'large' (walls higher than $15 \mathrm{~m}$, or $10-15 \mathrm{~m}$ high with a crest length of over $500 \mathrm{~m}$, or having a reservoir capacity of 1 million m3), 27 were 'medium sized' (with walls 8-10m high), and 192 were 'small' dams (walls less than 8m). However, according to Okoye and Achakpa (2007), there are a number of technical, financial and economic concerns in the development and management of dams in Nigeria. Some large dams are yet to be effectively harnessed, usually due to under- or non-development of downstream irrigation and under-utilisation of dam facilities. In most cases, stakeholders are not consulted or otherwise involved in planning, development and management of the nation's water resources. The result has been a vicious cycle of unreliable projects that provide services that do not meet consumer needs or are often abandoned halfway without completion (Babatunde and Low, 2013; FGN, 2012, 2004, 2003; Okafor, 2013; Okoye et al, 2007). The country currently lacks the capacity to build large dams. As a result, the construction of large dams has been with the assistance of foreign countries and their agents both financially and technically. 
In particular, the State-Owned Enterprise (SOE) China Geo-Engineering Corporation (CGC) has become a prominient Chinese construction company active in Nigeria. It has been present in the country since the 1980s, when it started digging boreholes. Since then it has been involved in numerous projects, including Kebbi Airport, a major water supply project in Gombe and the construction of the Sabke Dam. CGC has also branched out from construction and is involved in oil exportation for its major shareholder, Sinopec. CGC has no formal corporate social responsibility programme, but does apparently drill boreholes free of charge in impoverished communities at the behest of the government (CGC, 2009). CGC has more than 200 Chinese staff in Nigeria, which is the company's biggest African operation. CGC's main selling point in Nigeria is price, but the company has aspirations to raise its quality and service provision levels so that it can compete on level terms with Nigeria's most powerful construction company, Germany’s Julius Berger. (CGC, 2009, Mthembu-Salter, 2009)

In 2008, CGC entered into a contract to build a 100MW hydropower plant for the Power Holding Company of Nigeria (PHCN) and the Zamfara State government. The project, located in Gotowa village, would have had the potential to provide irrigation for 10,000 hectares of land for the production of rice and tomatoes downstream from the 2 billion cubic metres dam. The US\$ 163 million project was scheduled to start providing power to the national grid in the first quarter of 2011 and was seen by both the government and the financiers as more appropriate for the region compared to some of the ambitious thermal power projects launched in other parts of the country that have had a varied success rate in coming to completion. Finance for the project was to come from the China Export-Import Bank (ExIm) to be guaranteed by Sofitel Capital Corporation and Intercontinental Bank Plc (now defunct), who would maintain the project for seven years. Discussions were also made between Zamfara's government and PHCN on a power-purchase agreement to cover the plant's output. However, after the initial assessment and community consultations that spanned three years, the project failed to take off.

Zamfara State is largely agrarian, with a population of about three million, and is located in North-Western Nigeria. Nearly four million hectares of land are cultivated, which represents about 30 percent of the total land area. The location of the proposed dam cut across two Local Government Areas, namely Zurmi and Shinkafi (see map 1). Nine communities were identified as closest to the dam site and would be affected by relocation. A profile of these communities shows that all the communities currently lack motorable roads , potable water, electricity, health facilities and schools. In essence all the communities are very poor in terms of infrastructure, income and education. Local communities depend largely on subsistence farming.

By conducting the stakeholder mapping we found highly complex interactions between the numerous stakeholders at federal, state and local government of Nigeria, Chinese actors such as the Exim Bank and CGC, and civil society. Figure 2 indicates the different relations between various national, provincial and local government agencies as well as foreign investors, funders, NGOs etc.

The dominant actors in the Zamfara dam project included the Zamfara state government, led by the former Governor himself and some members of his cabinet, the CGC as the construction and management firm, the EXIM Bank of China that would largely fund the project. The state government was also expected to provide some of the funds with the assistance of a Nigerian Bank (the now defunct Inter Continental Bank, i.e. Central Bank in Figure 2).These are the most influential actors in terms of hydropower decision and development in Nigeria. Other important actors are the communities, including marginalised people and traditional institutions, that would host the project and which are expected to enjoy some of the benefits of the project and bear the full negative impacts (see Figure 2). In terms of power these actors have very low influence on large dams' decision in Nigeria, especially community members. Traditional institutions can influence government decisions only marginally by negotiating compensation and relocation issues with local government officials. Other actors with marginal and very low influence on dam development in Nigeria are research institutions which mainly provide scientific advice and information to the government in relation to hydrological and environmental aspects (such as the National Institute of Social and Economic Research NISER and Uthman Dan Fodio University). International institutions, NGOs and civil society organizations (Note 2) also provide some advice and information on hydropower dams and sometimes they support opposition campaign in relation to social and/or environmental controversial projects.

\section{Nigerian Politics and the Zamfara Dam Project}

The key question we ask is why, despite the evident need for hydropower and water management, the existence of a financier and dam builder, and the regulatory architecture in Nigeria did the project fail to materialise? As noted CGC has a long history in Nigeria and is trusted. As one high ranking government official in Abuja stated: "I know that CGC have been doing a lot of works across Nigeria especially in Abuja. They are also into a lot of construction works here in Nigeria especially our public water works". The government official noted: "I would 
say they are doing well. I know that they built some irrigation dams in some parts of northern Nigeria including Gombe and Katsina. They are in fact becoming more and more visible in the construction industry in Nigeria today" (Interview, 10 November, 2014). Another government official in the state corroborated this: "CGC is handling different projects in the state. The Gusau waterworks is a project CGC is handling. Then we have the street lights, solar powered and there are plans for them to invest in agriculture. The state government is providing much of the money for these projects” (Interview, 16 September, 2014).

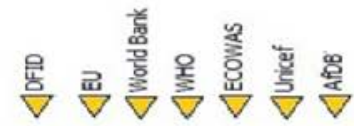

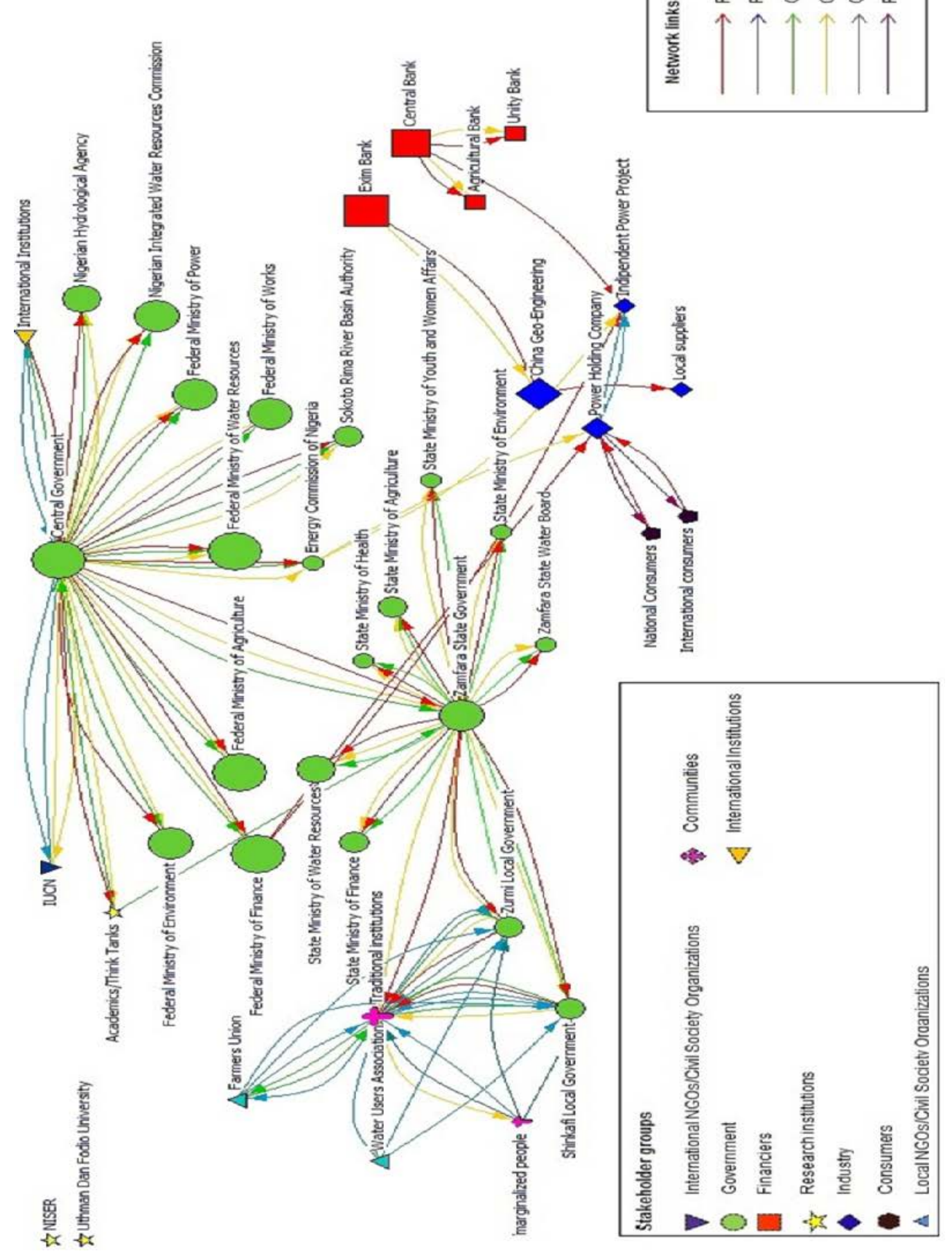


Figure 2. Stakeholder Map of Zamfara Dam Project. Note: the size of the nodes in the network (each node corresponds to an actor) indicates the different power of the identified actors in terms of influence on hydropower decision and development in Nigeria

One of the main reasons for the failed dam we found was that the negotiation process for the construction of the Zamfara dam was not opened to the federal regulatory body for dam construction in Nigeria (the Federal Ministry of Water Resources - FMWR) as stipulated by the existing legislation. In other words, the FMWR was not involved in the negotiation and plan to build the dam. The state did not seek for license from the Federal Government as requested. Though the federal government is presently encouraging the construction of hydropower dams of various sizes in the country project proponents are expected to apply for a licence to embark on such projects from the ministry. According to the state government official interviewed in Abuja (September 16, 2014), this is a law that has been flouted over the years by states. The Zamfara dam has not been an exception. It did not appear anywhere on the records of the ministry. According to this official of the FMWR

"The case of Gotowa dam is unknown to us. Even if the Zamfara state government were to build it as you said, they were supposed to apply for license from the FMWR but we didn't get any of such application. Some few states that have built some irrigation dams and waterworks have not been following this simple legislation. For large dams construction, the Federal Government is in charge of such large projects. They are subject to approval at the Federal Executive Council” He stated further that The officials of the federal ministries of water resources, finance, works and agriculture. Most dams in Nigeria are for water supply and agriculture. Sometimes ministry of power is involved in case the dam would also generate electricity. Energy Commission of Nigeria is also involved in case of power generation. It is only recently that hydropower dams are beginning to get attention from state governments unlike all the old hydropower dams that belong to the federal government".

On the negotiation process for the construction of a new dam, the usual procedure is once a dam project is identified, the Federal Executive Council will meet and debate the submission of the FMWR and provide approval for the project to take off including the release of the take-off grant. All dam projects are handled by the federal government through the FMWR. The federal government does most of the negotiations. States are also encouraged to build both irrigation and hydropower dams without the usual procedure of dams like the federal government, but they will have to get the licence from the FMWR to monitor operations.

The negotiation for the Zamfara dam, though a state initiated dam, did not follow the procedure laid down by the FMWR. According to a top government official (September 16, 2014) in the Zamfara State Ministry of Agriculture and Water Resources,

'the negotiation was actually between the [former] Governor [of Zamfara State], his close aides, few ministry officials and the CGC officials. I don't know if the negotiation involved government officials in Abuja especially those in the ministries of water resources and power. Usually there is a procedure for all these things but the whole process was not open to many top government officials until it got to the stage of budget allocation. In the course of negotiation for project, the governor and his team actually travelled to China. The whole process was actually between few government officials and CGC”.

This practice of elite brokerage has been observed elsewhere in Africa regarding Chinese investments (Carmody et al, 2012; Corkin 2011) as well as the tendency to flout regulations (Hensengerth, Haglund). Furthermore, the FMWR interviewed stated that the invitation to tender for a project may be published in the newspapers for competitive bidding or a specific company is invited to bid. When a company submits a quotation, it is brought to the executive council meeting and subsequently handled by a team constituted by the government. The money for such project would have to be put in the annual budget for appropriation. Then when it is finally approved, the money is released in tranches for project execution. The Zamfara dam followed this process according to the government official interviewed (September 16, 2014) because the project was already mentioned in the budget and money voted for it. The selection of CGC was based on their track records and their other involvement in the execution of projects in the state especially the Gusau urban water supply project.

Another reason is the lack of proper negotiation and adequate consultation as regards the Zamfara state project. According to Okoye and Achakpa (2007), the World Commission on Dams WCD found that there has been a generalized failure globally to include and recognize affected people and empower them to participate in decision making. Insufficient time, resources and information have been made available for public consultations. Opportunities for participation, when provided often occur late in the process and are limited in scope. This has magnified the negative impacts of such projects and alienated affected communities, leading not only to serious social impacts but also schedule delays, cost overruns and poor financial and economic performance. According to a State government official interviewed commenting on the steps to approve a Chinese contractor to tender 
and build a Chinese overseas dam project,

There is a dam here in Gusau, the Gusau dam which was designed for water supply and small irrigation. The dam has been up and running for quite a while, around 10 years or so. The whole process is usually between the government and the company handling the project. Normally, the invitation to tender maybe published in the newspapers for competitive bidding or a specific company is invited to bid. When a company submits quotation, it is brought to the executive council meeting and subsequently handled by a team constituted by the government. The money for such project would have to be put in the annual budget for appropriation. Then when it is finally approved, the money is released in tranches for project execution. The Zamfara dam followed this process because the project was already mentioned in the budget and money voted for it. Up till now they have not closed the budget envelop in the annual budget even though the project failed to take off. The selection of CGC was based on their tract records and their other involvement in the execution of projects in the state especially the Gusau urban water supply project”.

This lack of wider negotiation and scrutiny was evident in terms of community consultations. Many of the villagers claimed that they were not involved in the consultation process. In a FGD session in Mokosa village (September 4, 2014), a male participant claimed that "Yes. Sometime long ago, I personally assisted some Chinese people that visited the area for some measurement on the dam site. I assisted them by holding measuring tape for them. They carried out some measurements on the site of the river and even dug a sample of soil in the river and went away with it. We took them to the other bank of the river to the north-west; they finished their work and went away". On the other hand, another villager from Kuturu claimed that "We have not been involved in any consultation process and we only received information about the dam from our village leaders". This individual quote was supported by survey data. Although 60.4 percent of the respondents insisted there were no consultations, 34.9 percent attested there were some consultations by means of village meetings with the elders. Close to one-third of the respondents (27.5 percent) recalled that issues of resettlement featured prominently in the agenda of their discussions, with plans for resettlement at Gidan Jaja and Moriki. Compensation plans for crops have been drawn up as stated by 22.8 percent of the respondents. Our findings revealed that the community members knew nothing about the dam until the state government officials and the representative of CGC came to visit the proposed dam site and informed them of the plan to relocate the affected communities as a result of the dam construction.

So far the construction has not started yet. According to the state government official interviewed (September 16, 2014), "nothing has been done so far in terms of construction works. The enumeration of the communities was carries out for compensation purposes. The communities were also informed that some of them would be relocated from their present domain. Also the EIA was awarded to Poseidom Technologies in Kaduna and aerial survey commenced in early 2008 with 50 percent of the money for the EIA paid to the consultancy company. But there is no evidence that the actual was conducted, neither was the aerial survey concluded. It has been more than seven years now that nothing has been done on the project. But the budgetary allocation has been kept open over the years. That means the idea of the project has not been totally foreclosed".

Perhaps the most important factor that stalled the execution of the project, apart from funding, was the failure of the Ex-Governor to be re-elected into office for the second term of four years. According to a state government official:

"well, the Governor and his team were at the forefront of this negotiation and I think everything went smoothly. He even travelled out to China on one or two occasions in respect of the project. The major impediment was the issue of finance. I believe that if the [Ex-]Governor had been re-elected, he would have continued with the project eventually. It's all about lack of political will and lack of continuity in government projects. Most projects are often politisiced as a result when a government leaves and another one comes in they often change focus. The project was his original idea, to open up the area where he hails from. But I think the initial delay was caused by the recession experienced worldwide at that time and the dwindling resources in the country. You know states like Zamfara have little internally generated revenue and so it depends almost entirely on the allocation from the federal government to execute its development projects and pay workers' salaries. Around the time the project was to commence, the resources of the state shrunk and the state could not fulfil its part of the financial commitment, though the foreign partners were willing to commence the work at that time. Since the present Governor [ came [in 2011-2015], his interest is not in the project. He is more concerned with the construction of roads and urban water supply. That is the unfortunate story of the dam". The situation is not strange in Nigeria where political leaders wield enourmous powers in the use of allocations from the federal government and revenues generated within each state. States hardly have development blueprints and infrastructural projects are dependent largely on the choice of the states executive. In order words, the choice to 
continue, or otherwise, with an existing/ongoing project rests largely with the Governor of a state. It is as a result of this that abandoned projects litter the nooks and cranny of the nation.

The findings from the various community surveys indicated that the communities fully accepted the idea of the project. They were hoping that the dam project will bring development benefits to these communities. Some communities however expressed reservation about the idea of resettlement. No further consultations have taken place beyond the initial ones in 2007 and 2008. They were not informed of the reason why the project did not take off eventually. So there has been a lot of agitation on the part of the communities on the status of the project. The envisaged construction of the dam, raised the hopes and expectations of the inhabitants of the dam area as 69.8 percent expected the provision of the needed infrastructure and social amenities such as roads, electricity access, potable water access, schools, while 17.4 percent perceived the possibility of job creation. Additional 6.7 percent of the respondents felt that the dam would improve their overall standard of living. Although 89.3 percent of the respondents agreed there has not been any construction work at the proposed dam site in spite of the repeated promises made by government between 2008 and 2011, a majority (49.0 percent) of the respondents do not know the cause of the delay.

\section{Conclusion}

This paper examined the socio-political situations that led to the failure of the proposed Zamfara dam project which was to be built by the China Geo-Engineering Corporation in Nigeria. Like many other African countries, Nigeria has embraced China as an economic partner. This does not, however, mean that the Sino-Nigerian alliance does not face significant challenges that must be resolved if both are to realise their economic ambitions (Egbula and Zeng, 2011). One often cited hurdle in the economic relationship between China and Nigeria is Nigeria's political unpredictability. Chinese investors are considered to be more comfortable with risk than their Western counterparts, yet if signed contracts are routinely reviewed and suspended when power changes hands, their appetite for risk is likely to fade. Even with the perils of changeable government contracts, Chinese investors prefer public sector over private sector partners, which are seen as even less reliable (Mthembu-Salter, 2011).

Dams are very important and crucial to development in Nigeria. In the northern part of the country where there is gross shortage of electricity and water for a predominantly agrarian populace, the investment in dams is well received. While federal and state governments assume greater responsibility for overall management of the nation's water resources in most cases stakeholders are not consulted or otherwise involved in planning, development and management of the nation's water resources. The result has been a vicious cycle of unreliable projects that provide services that do not meet consumer needs, are underutilized or outright abandonment of such projects like the case of the Zamfara dam.

In conclusion, though, Chinese firms have brought into the Nigerian construction industry intense competition on project finance and speed of delivery, nevertheless, joint ventures based on deep appreciation and understanding of each other's culture and influences on business operations are essential, as strategic partnerships between Chinese firms and Nigerian government at different levels cannot be ignored. Considering the fact that political factors played a significant role in the failure of the Zamfara dam project, it is suggested that motivation for and implementation of development projects of this nature should transcend political whims and caprices of politicians and ensuring more transparency and broad consultation.

Acknowledgement: We are grateful to the Economic and Social Research Council (ESRC) for funding this research as part of the 'China goes global' project under the Rising Powers programme (ESRC reference ES/J01320X/1).

\section{References}

African Development Bank. (2010). Infrastructure Deficit and Opportunities in Africa. Economic Brief. Volume1, Issue September 2010.15pp

Alao, A. (2010). Chinese Business Interests and Banking in Nigeria. South African Institute of International Affairs (SAIIA). Policy Briefing 20.

Alhassan, H. S. (2009). Viewpoint - Butterflies vs. hydropower: Reflections on large dams in contemporary Africa. Water Alternatives, 2(1), 148 - 160. Retrieved from http://www.water - alternatives.org

Alike, E. (2011). Nigeria: FG angry with Chinese firms over power projects. Retrieved from http://www.allafrica.com/stories/printable/201102220719.html

Babatunde, O. K., \& Low, S.P (2008). Cross-cultural crises management on quality: a case study of Chinese 
contractors in Nigeria. In Feng, et al. (Eds.) Proceedings of CRIOCM 2008: Advancement of construction management and real estate, 31 October-3 November, Renmin University, Beijing, China. (pp. 347-352)

Babatunde, O. K., \& Low, S.P (2013). Chinese construction firms in the Nigerian construction Industry. Habitat International vol. 40 pp. 18-24.

Biersack, A. (2006). Reimagining political ecology: culture/power/history/nature. In A. Biersack and J.B. Greenberg (eds.) Reimagining political ecology. Durham: Duke University Press. Pp. 3-40.

Bosshard, P. (2009). China dams the world. World Policy Journal, 10, 43-51.

Bryant R (1997) Beyond the impasse: the power of political ecology in Third World environment research. Area, 29(1), 5-19.

Bryant, R. L., \& Bailey, S. (1997). Third World Political Ecology. London, New York.

Bury, J. (2008). Transnational Corporations and Livelihood Transformations in the Peruvian Andes: An Actor-Oriented Political Ecology. Human Organization, 67(3), 307-321.

Castellano, A, Kendal, A., Nikomarov, M., \& Swemmer, T. (2015). Brighter Africa: The grand Potemtial of the Sub-Saharan Electricity Sector. Mckingsey and Company. Retrieved from http://www.monetgas.com/Brighter\%20Africa\%20-\%20McKinsey\%202015.pdf

Center for Chinese Studies. (2006). China's Interest and Activity in Africa's Construction and Infrastructure Sectors. Centre for Chinese studies. Stellenbosch University.

CGC. (2009). CGC (China Geo-Engineering Corporation) Nigeria, Building Excellence. Kaduna: CGC.

Corkin, L. (2013). Uncovering African Agency: Angola’s Management of China’s Credit Lines. Farnham: Ashgate.

Corkin, L. B. C., \& Davies, M. (2008). China's Role in the Development of Africa's Infrastructure. SAIS working Papers in African Studies. 04-08. Centre for Chinese Studies, Stellenbosch University. Retrieved from

https://www.sais-jhu.edu/sites/default/files/China's-Role-in-the-Development-of-Africa's-Infrastructure.pdf

Daouda, C., Sven, G., \& Andreas, N. (2014). State-Directed Multi-National Enterprises and Transnational Governance: Chinese Investments in Africa, Corporate Responsibility and Sustainability Norms. Center for Chinese Studies Discussion Paper. $\quad$ Retrieved from http://www.ccs.org.za/.../2014/.../CCS_DP_Corporate_Responsibilities_Cisse_Grimm_Nolke

Deng, B. (2011). Ambassador Deng gave an interview to the Nations Newspaper. In Embassy of the Peoples Republic of China in the Federal Republic of Nigeria. Retrieved from http://www.ng.chinaembassy.org/eng/xw/t888594.htm

Federal Government of Nigeria (FGN). (2003). National Energy Policy.

Federal Government of Nigeria (FGN). (2004). National Water Policy.

Federal Republic of Nigeria. (2012). The Project for Review and Update of Nigeria National Water Resources Master Plan Progress Report-2 Summary. Federal Ministry of Water Resources and Japan International Cooperation Agency.

Foster, V., Butterfield, W., Chen, C., \& Pushak, N. (2008). Building Bridges: China's growing role as infrastructural financier for sub Saharan Africa. The International Bank for Reconstruction and Development, The World Bank.

Grimm, S. N., \& Andreas, D. C. (2014). State-Directed Multi-National Enterprises And Transnational Governance: Chinese Investments In Africa, Corporate Responsibility And Sustainability Norms. Discussion Paper 1, Stellenbosch. Aceessed on March 15, 2015. Retrieved from http://www.die-gdi.de/uploads/media/CCS_DP_Corporate_Responsibilities_Cisse_Grimm_Nolke_20141.p $\mathrm{df}$

Humphrey, J., \& Messner, D. (2005). The impact of the Asian and other drivers on global governance. Retrieved from http://www.ids.ac.uk/ids/global/pdfs/AsianDriversGovernancepaper05.pdf

Humphrey, J., \& Messner, D. (2006). China and India as emerging global governance actors: Challenges for developing and developed countries. IDS Bulletin, 37(1), 107-114.

International Energy Agency. (2015). World Energy Outlook 2015. Electricity access database. Retrieved from 
http://www.worldenergyoutlook.org/resources/energydevelopment/energyaccessdatabase/

International Rivers. (2013). Chinese Dams in Africa. Retrieved from http://www.internationalrivers.org/campaigns/chinese-dams-in-africa

IRN (International Rivers Network). (2007). Before the deluge: Coping with floods in a changing climate. International Rivers Network. Retrieved from http://www.internationalrivers.org/files/Deluge2007_full.pdf

Jiang, G., \& Mirza, H. (2010). Relationship between Transnational Corporations and Chinese State-Owned Enterprises. Transnational Corporations Review, 2(4), 27-38.

Kaplinsky, R., \& Messner, D. (2008). Introduction: The impact of Asian drivers on the developing world. World Development, 36(2), 197-209.

Kılıç, S. (2013). China’s new strategy to develop relations with Africa: Dam Construction. Todays Zaman. http://www.todayszaman.com/news-309257-chinas-new-strategy-to-develop-relations-with-africa-dam-cons truction.html

Long, N. (1994). 'From paradigm lost to paradigm regained?' in Norman Long and Ann Long (Eds), Battlefields of Knowledge: The interlocking of theory and practice in social research (Routledge: London).

Mohan, G., \& Lampert, B. (2013). Negotiating China: Reinserting African agency into China-Africa relations. African Affairs, 112(446), 92-110.

Mthembu-Salter. (2009). Elephants, Ants and Superpowers: Nigeria's relations with China. South African Institute of International Affairs (SAIIA), Occasional Paper No 42.

Naidu, S. (2007). China-African Relations in the 21st Century: A “Win-Win” Relationship. In: Lee, Henning Melber, Sanusha Naidu and Ian Taylor (Eds) China in Africa. Current African Issues, 33. Nordiska Afrikainstitutet, Uppsala, 41-46 Accessed on 10/11/2015.

Nigerian Compass. (2012). Why Sub standard Chinese goods flood Nigeria market. Retrieved from http://www.compassnewspaper.org/index.php/special_desk/business_news/10682

Obayuwana, O. (2013). Jonathan in China: Looking At The Business For Nigeria. The Guardian Newspaper. http://www.ngrguardiannews.com/index.php/world-news/127007-jonathan-in-china-looking-at-the-business -for-nigeria

Ofoezie, I. E. (2002). Human Health and Water Resources Development in Nigeria: Schistosomiasis in Artificial Lakes. Natural Resources Forum, 26, 150-159.

Okafor, O. (2013). FG Approves $\$ 1.72$ bn Counterpart Funding for Hydro Dams. Thisday Newspaper. Retrieved from http://www.thisdaylive.com/articles/fg-approves-1-72-bn-counterpart-funding-for-hydro-dams/149335/

Okoye, J. K., \& Achakpa, P. M. (2007). Background study on water and energy Issues in Nigeria to inform the National Consultative Conference on Dams and Development. Submitted to the The Federal Ministry of Agriculture and Water Resources and Society for Water and Public Health Protection. Retrieved from http://www.unep.org/dams/files/nigeria_final_report_on_background_study_22_may_07.pdf

Paulson, S., Gezon, L., \& Michael, W. (2003). Locating the Political in Political Ecology: An Introduction. Human Organization, 62(3), 205-218.

Peet, R., \& Michael, W. eds. (2004). Liberation Ecologies: Environment, Development, Social Movements. New York: Routledge.

Peluso, N. (1996). Fruit Trees and Family Trees in an Anthropogenic Forest: Ethics of Access, Property Zones, and Environmental Change in Indonesia. Comparative Studies in Society and History, 38(3), 510-548.

Richter, B. D. et al. (2010). Lost in Development's Shadow: The Downstream Human Consequences of Dams”, Water Alternatives,3(2) (June 2010), 14-42.

Schiffer, E. H. J. (2010). Net-Map: Collecting Social Network Data and Facilitating Network Learning through Participatory Influence Network Mapping. Field Methods, 22, 231.

Schmitz, H. (2006). Asian drivers: Typologies and questions. IDS Bulletin, 37(1), 54-61.

Sklair, Leslie. (2001). The Transnational Capitalist Class. Cambridge: Blackwell.

Tan-Mullins, M. (2007). The state and its agencies in coastal resources management: The political ecology of fisheries management in Pattani, southern Thailand. Singapore Journal of Tropical Geography, 28, 348- 
361.

Tiffen, A. (2014). The new Neo-Colonialism in Africa. Global Policy Acceesed on 09/11/2015. Retrieved from http://www.globalpolicyjournal.com/blog/19/08/2014/new-neo-colonialism-africa

Ukaoha, K. (2009). An overview of China-Nigeria trade relations. In a presentation at the study dissemination workshop on China-Nigeria relations organized by the African economic research consortium (AERC), Nairobi Kenya.

Urban, F., Nordensva“rd, J., Wang, Y., Khatri, D., \& Mohan, G. (2011). China and the African oil sector: channels of engagement, motives, actors and impacts. Brighton: IDS Rising Working Paper, IDS.

Urban, F., Nordensvärd, J., Khatri, D., \& Wang, Y., (2013). An analysis of China’s investment in the hydropower sector in the Greater Mekong Sub-Region. Environment, Development and Sustainability, 15(2), 301-324.

Veilleux, J. C. (2013). The Human Security Dimensions of Dam Development: The Grand Ethiopian Renaissance Dam. Global Dialogue Volume 15, Number 2, Summer/Autumn 2013-Water: Cooperation or Conflict? Retrieved from http://www.transboundarywaters.orst.edu/publications/publications/Veilleux_GLOBAL\%20DIALOGUE_V 15_GERD.pdf

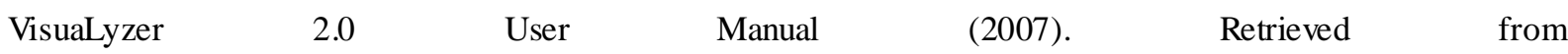
http://www.mande.co.uk/blog/wp-content/uploads/VisuaLyzer\%20User\%20Manual\%202.0.pdf

Whitehead, M., Jones, R., \& Martin, J. (2007). The Nature of the State: Excavating the Political Ecologies of the Modern State. Oxford: Oxford University Press.

Wiles, J. L., Rosenberg, M. W., \& Kearns, R. A. (2005). Narrative analysis as a strategy for understanding interview talk in geographic research. Area, 37(1), 89-99.

Wolcott, H. F. (1994). Transforming qualitative data: Description, analysis, interpretation. Thousand Oaks, CA: Sage.

Yin, R. K. (2009). Case study research: Design and methods (4 ed.). Los Angeles, CA: Sage.

\section{Notes.}

Note 1. Network data were visualized using Visualyzer software (VisuaLyzer 2.0 User Manual, 2007).

Note 2. Such as The UK Department for International Development (DFID), The European union (EU), The World Health Organization (WHO), The Economic Community Of West African States (ECOWAS), African development Bank (AFDB), Unicef, the International Union for Conservation of Nature (IUCN).

\section{Copyrights}

Copyright for this article is retained by the author(s), with first publication rights granted to the journal.

This is an open-access article distributed under the terms and conditions of the Creative Commons Attribution license (http://creativecommons.org/licenses/by/4.0/). 